\title{
A Longitudinal Analysis of the Stability of Household Money Demand
}

\author{
Jan Tin \\ U.S. Department of Commerce, Washington DC, USA \\ E-mail: jantin4@hotmail.com \\ Received March 15, 2011; revised May 5, 2011; accepted May 20, 2011
}

\begin{abstract}
Past aggregate time-series studies, conducted under the assumption of a representative economic agent, frequently show that the demand for narrowly defined M1, especially non-interest-yielding demand deposit, is unstable during periods of financial innovations. Whether this is longitudinally the case among life-cycle savers is unclear. This study utilizes longitudinal data to take another look and find that volatility in the demand for non-interest-earning checking accounts in the mid and late 1990s is attributable solely to the portion held for the transactions motive. When the conventional Baumol-Tobin model is extended to include human capital and family formation variables representing the life-cycle motive, equilibrium money demand is a stable function of both economic and demographic variables.
\end{abstract}

Keywords: Life-Cycle Motive, Money Demand Stability, Longitudinal Data

\section{Introduction}

A stable money demand or velocity of money in circulation is theoretically a matter of fundamental importance in order for monetary policies to have predictable impacts on general economic activities, as suggested in the Keynesian IS-LM framework [20] and the classical quantity theory of money [16]. Empirical studies on money demand were mostly conducted within the frameworks of the inventory-theoretic transactions approach [12,21] and the asset approach [3]. Before the 1970s, the focus of most time-series studies was on the relative importance of the scale variables and interest rate [13]. The focus of cross-sections studies was also on the relative importance of the scale variables determining long-run money demand, but the rate of interest was often omitted from the analysis because of the lack of micro data $[2,5,22,23]$. During the 1970s and 1980s, the discovery of a stable partial dynamic adjustment model of aggregate money demand [14] and its collapse during the 1974-1976 and 1979-1982 periods greatly diverted the attention from both long-run aggregate money demand and cross-sectional studies $[1,11,17,18]$. In the post-1990 literature, the attention has shifted to the search for a stable long-run aggregate money demand based on the cointegration approach. However, findings in the early 1990s were inconclusive [6,7,15,25], while the banking reform and retail sweep programs of the 1994-1999 period have further challenged the existence of a stable long-run aggregate money demand in the United States [8-10,19].

Nevertheless, a moment of reflection suggests that time-series studies are mostly conducted under the assumption of a representative economic agent whose parametric behavior is presumed to be identical to those of the underlying individuals with different propensities to save. At the microeconomic level, equilibrium demand for money is not only a function of the transactions motive but also a function of the life-cycle and other motives, as postulated by Keynes [26]. Volatility in the quantity demanded for the transactions motive alone may not necessarily destabilize the overall equilibrium level if a stable relationship exists between the life-cycle motive and money demand. In fact, empirical findings in recent cross-section studies indicate that the life-cycle motive has an important role to play and that money demand functions are not homogeneous among money-holders with divergent socio-economic backgrounds [4,27].

The purpose of this study is to examine the microfoundations of aggregate money demand and its stability during periods of financial innovations by utilizing longitudinal data within the frameworks of the inventory-theoretic transaction approach and the life-cycle hypothesis [2]. When data on money demand are free 
from the identification problem and the assumption of a representative economic agent, findings reveal that the demand for transactions money balances is longitudinally stable during the 1996-1999 period of banking reform and financial innovation. The evidence also suggests that instability in money demand function is largely related to the omission of a life-cycle motive from the conventional Baumol-Tobin model.

This paper is organized in the following manner. Section 2 discusses the restricted and unrestricted econometric models employed in this study. Section 3 explains data sources and definitions. Section 4 presents empirical findings, and a brief conclusion is given in the final section.

\section{Econometric Models}

Following the literature, the inventory-theoretical transactions model $[3,4]$ widely adopted in past studies [11, $15]$ can be stated in log-linear form as

$$
\ln m_{i t}=\alpha+\beta \ln y_{i t}+\theta \ln r_{i t}+\varepsilon_{i t}
$$

where $\ln m_{i t}$ is the $\log$ of real money demand at time $t$ for individual $\mathrm{i}, \ln y_{i t}$ is the $\log$ of real income as a proxy for total transactions, $\ln r_{i t}$ is the $\log$ of interest rate on an alternative asset, and $\varepsilon_{i t}$ is an error term representing omitted variables. The restrictions, $\beta>0$ and $\theta<0$, are assumed to hold.

At the macroeconomic level, since money demand, real income, and interest rate are simultaneously determined, ordinary least squares (OLS) estimates of income and interest elasticities are likely biased and may even be spurious. In past studies, the difficulty is usually overcome by employing cointegration techniques such as the stationarity and cointegration tests. At the microeconomic level, since income and prices are predetermined cointegration techniques cannot be easily applied. Nevertheless, OLS estimates of income and interest elasticities in the standard Baumol-Tobin model may still be biased, because, according to the life-cycle hypothesis [9], human capital and family formation variables not only have direct impacts on the quantity of saving held in the form of monetary assets but also interact with real income and time preference. In order to obtain unbiased estimates, human capital and family formation variables representing the life-cycle motive must be separated from the error term [27]. Rewriting equation (1) gives

$$
\ln m_{i t}=\alpha+\beta \ln y_{i t}+\theta \ln r_{i t}+\gamma D_{i t}+\mu_{i t}
$$

where $D_{i t}$ is a vector of demographic variables with the corresponding set of parameters, $\gamma^{\prime}$, and $\mu_{i t}$ is an error term with zero mean and constant variance. If $\gamma=0$, Equation (2) reduces to Equation (1) or its aggregate counterpart under the assumption of a representative economic agent. In order to facilitate the analysis, Equations (1) and (2) will be referred to as the simple model and the life-cycle model, respectively, whenever appropriate.

Econometrically the simple or life-cycle model per se cannot be used to test the stability of money demand unless it is disaggregated into individual components for each of the underlying cross-sectional time periods. Unrestricting Equation (2) gives

$$
\begin{aligned}
& \ln m_{i 1}=\alpha_{1}+\beta_{1} \ln y_{i 1}+\theta_{1} \ln r_{i 1}+\gamma_{1}^{\prime} D_{i 1}+\mu_{i 1} \\
& \ln m_{i 2}=\alpha_{2}+\beta_{2} \ln y_{i 2}+\theta_{2} \ln r_{i 2}+\gamma_{2}^{\prime} D_{i 2}+\mu_{i 2} \\
& \ln m_{i T}=\alpha_{T}+\beta_{T} \ln y_{i T}+\theta_{T} \ln r_{i T}+\gamma_{T}^{\prime} D_{i T}+\mu_{i T}
\end{aligned}
$$

Subscripts 1, 2, and T stand for the first, second, and the final survey periods, respectively. If $\gamma_{1}^{\prime}=\gamma_{2}^{\prime}=\cdots$ $=\gamma_{T}^{\prime}=0$, equation (3) reduces to its unrestricted counterpart for the simple model. Based on the restricted and unrestricted models, the hypothesis of a stable money demand can be tested by Chow statistics derived from the sum of squared residuals and the associated degrees of freedom.

\section{Data Sources and Definitions}

The 1996 panel of the Survey of Income and Program Participation (SIPP) conducted by the United States Bureau of the Census from 1996 through 1999 is the primary source of data for this study. The 1996 SIPP panel is selected mainly because it contains time-series cross-sections data on financial assets, household income, and demographic variables and enables this study to examine the stability of money demand during the 1996-1999 period of financial innovations. Longitudinal data for the entire 1996-1999 period are constructed by merging data in the core and topical modules of waves 3 , 6,9 , and 12 for those who are 15 years of age or over. Structural breaks of the 1974-1976 and 1978-1982 periods cannot be examined in this study because of the lack of SIPP data. Likewise, data for 1995 are not available in SIPP and must be excluded from regression analysis. Although the 1993 SIPP panel contains data on financial assets in 1994, the samples are not the same as those in the 1996 SIPP panel. Consequently the two panels cannot be combined together for regression analysis. In general SIPP is a short panel with different samples and sample sizes in different panels which cannot simply be combined together to obtain a workable longitudinal file with more time-periods and observations. Real quantities are obtained by deflating nominal quantities by the Consumer Price Index (CPI) compiled by the U. S. Bureau of Labor Statistics.

Since data on currency are not available in SIPP, money demand is narrowly defined as non-interest- 
earning checking accounts possessed by householders in their own names or jointly with spouses. The rate of interest is measured by the ratio of gross return on interest-earning checking accounts, regular or passbook savings, money market deposits, and certificates of deposit to the gross amount of these assets. Household income is measured by the sum of labor and nonlabor incomes. Labor income consists of wages, salaries, and self-employment income, while nonlabor income is the sum of interests and dividends from financial assets, retirement incomes, Social Security income, government transfers, and other types of income. A householder is defined as a reference person in whose name the home is bought or rented. In this study, the life-cycle motive is measured by age, age squared, education, marital status (Married = $1 ; 0$ otherwise), number of children (with children $=1 ; 0$ otherwise), gender (female $=1 ; 0$ otherwise), and race (African American $=1 ; 0$ otherwise).

\section{Regression Results}

Restricted and unrestricted OLS regression results for the simple and life-cycle models are reported in Table $\mathbf{1 .}$ Income elasticity is positive and significant at the $1 \%$ level in each regression of the simple and life-cycle models. In the simple model, the longitudinal estimate of income elasticity for the entire 1996-1999 period is approximately 0.21 , about eight-percentage points smaller than the 0.29 in the life-cycle model. This means that a rise real income by $100 \%$ would raise money demand by about $29 \%$ in the life-cycle model and only $21 \%$ in the simple model. Similarly cross-sectional estimates of income elasticity in 1996, 1997, 1998, and 1999 in the simple model are considerably smaller than their counterparts in the life-cycle model. More specifically, cross-sectional estimates in the simple model range from 0.19 in 1998 to 0.22 in 1996 or 1997, whereas cross-sectional estimates in the life-cycle model range from 0.28 in 1998 to 0.31 in 1999 . Within the simple model, the longitudinal estimate is somewhat smaller than the cross-sectional estimates in 1996 and 1997. It is, however, about two-percentage points greater than the estimate in 1997 and is quite similar to the estimate in 1999. For the life-cycle model, the longitudinal estimate is smaller than the 1996 or 1999 estimate but greater than the estimates in 1997 and 1998.

As predicted by the theory, estimates of interest elasticity are negative in all regressions and significant at the $5 \%$ level in nearly all regressions. Longitudinal estimates in the simple and life-cycle models are -0.05 and -0.04 , respectively. A rise in the rate of interest on near monies by $100 \%$ would therefore raise money demand by about $5 \%$ in the simple model and $4 \%$ in the life-cycle model.
Cross-sectional estimates for 1996, 1998, and 1999 in the simple model are greater than their counterparts in the life-cycle model in absolute terms. However, the estimates in 1997 are not significantly different from zero at the $5 \%$ level in both models. For the simple model, the longitudinal estimate is smaller than the cross-sectional estimate in 1996 or 1998 but greater than the cross-sectional estimates in 1997 and 1999. For the life-cycle model, the longitudinal estimate is somewhat smaller than the cross-sectional estimates in 1996 and 1998 but greater than the cross-sectional estimates in 1997 and 1999.

In addition to the indirect impacts of the life-cycle motive on money demand via its interaction with income and interest rate, human capital and family formation variables also exert direct impacts on money demand. Qualitatively the coefficients of age and age squared are opposite in sign, indicating that the demand for narrow money initially declines with age, reaches a minimum, and then rises. Money demand increases with education. Married people hold less and spend more than those who are separated, divorced, widowed, or never married. Households with the presence of children spend more than those without any children. Women hold less than men. African Americans tend to spend more than Whites. Quantitatively the coefficient of marital status is largest in magnitude, followed by the coefficients of race, children, gender, education, age, and age squared in absolute terms. Judging from the relatively large magnitudes of most demographic variables, the strength of the relationship between money demand and the life-cycle motive is quite strong. More importantly, the value of Chow statistic for the simple model is substantially greater than the critical value at the $1 \%$ level. The hypothesis of a stable money demand is evidently rejected. In contrast, the hypothesis cannot be rejected for the life-cycle model, because the value of Chow statistic falls far short of the critical value at the $1 \%$ level. Values of $R$ squared also indicate that the life-cycle model outperforms the simple model.

\section{Conclusions}

Intuition suggests that human capital and family formation variables change gradually over time, whereas economic variables, especially income and interest rate, may be quite volatile during periods of financial innovations and economic shocks. Indeed, findings in this study reveal that estimates of income and interest elasticities in the United States are not only volatile but also biased in the simple model during the mid and late 1990s. However, when the life-cycle motive is explicitly captured by the simple model, the demand for non-interest-earning 
Table 1. OLS regression results for restricted and unrestricted models with and without the life-cycle motive.

\begin{tabular}{|c|c|c|c|c|c|c|c|c|c|c|}
\hline \multirow[b]{2}{*}{ Explanatory } & \multicolumn{5}{|c|}{ Simple model } & \multicolumn{5}{|c|}{ Life-cycle model } \\
\hline & & & & & & & & & & \\
\hline Variables & 1996-1999 & 1996 & 1997 & 1998 & 1999 & 1996-1999 & 1996 & 1997 & 1998 & 1999 \\
\hline \multirow[t]{2}{*}{ Constant } & 0.0125 & -0.0850 & 0.0971 & -0.0681 & 0.0971 & $-2.9809 * * *$ & $-0.3289 * * *$ & $-2.7520 * * *$ & $-3.1188 * * *$ & $-2.7789 * * *$ \\
\hline & $(0.26)$ & $(0.73)$ & $(0.96)$ & $(0.77)$ & (1.12) & (18.23) & $(9.77)$ & $(8.74)$ & $(9.53)$ & $(8.11)$ \\
\hline \multirow[t]{2}{*}{ Real income } & $0.2113 * * *$ & $0.2177 * * *$ & $0.2247 * * *$ & $0.1947 * * *$ & $0.2101^{* * *}$ & $0.2949 * * *$ & $0.2951 * * *$ & $0.2916^{* * *}$ & $0.2835 * * *$ & $0.3067 * * *$ \\
\hline & (21.43) & (10.27) & $(11.80)$ & $(9.91)$ & (10.93) & (27.08) & (12.58) & (13.91) & (12.98) & (14.52) \\
\hline \multirow{2}{*}{$\begin{array}{l}\text { Rate of } \\
\text { return }\end{array}$} & $-0.0523 * * *$ & $-0.0649 * * *$ & $-0.0275^{*}$ & $-0.0742 * * *$ & $-0.0420 * * *$ & $-0.0350 * * *$ & $-0.0428 * * *$ & -0.0097 & $-0.0613 * * *$ & $-0.0239 * * *$ \\
\hline & $(7.70)$ & $(3.72)$ & $(1.81)$ & $(6.02)$ & $(3.51)$ & $(5.33)$ & $(2.54)$ & $(0.66)$ & $(5.13)$ & $(2.06)$ \\
\hline \multirow[t]{2}{*}{ Age } & & & & & & $-0.0145^{* * *}$ & -0.0096 & $-0.0117^{*}$ & $-0.0209 * * *$ & $-0.0156^{*}$ \\
\hline & & & & & & $(3.86)$ & $(1.30)$ & (1.67) & $(2.72)$ & $(1.86)$ \\
\hline \multirow[t]{2}{*}{ Age squared } & & & & & & $0.0003 * * *$ & $0.0002 * * *$ & $0.0002 * * *$ & $0.0003 * * *$ & $0.0003 * * *$ \\
\hline & & & & & & $(8.01)$ & $(3.31)$ & (3.64) & (4.79) & (3.93) \\
\hline \multirow[t]{2}{*}{ Education } & & & & & & $0.0793 * * *$ & $0.0826^{* * *}$ & $0.0766^{* * *}$ & $0.0831 * * *$ & $0.0761 * * *$ \\
\hline & & & & & & (24.18) & (11.74) & (12.01) & (12.99) & $(11.71)$ \\
\hline \multirow[t]{2}{*}{ Married } & & & & & & $-0.4443 * * *$ & $-0.4299 * * *$ & $-0.4393 * * *$ & $-0.4292 * * *$ & $-0.4747 * * *$ \\
\hline & & & & & & (19.49) & $(9.03)$ & $(10.02)$ & $(9.55)$ & (10.35) \\
\hline \multirow[t]{2}{*}{ Children } & & & & & & $-0.1861 * * *$ & $-0.2058^{* * *}$ & $-0.1709 * * *$ & $-0.1789 * * *$ & $-0.2024 * * *$ \\
\hline & & & & & & $(8.20)$ & $(4.41)$ & $(3.96)$ & $(3.96)$ & $(4.28)$ \\
\hline \multirow[t]{2}{*}{ Female } & & & & & & $-0.1751 * * *$ & $-0.1922 * * *$ & $-0.2159 * * *$ & $-0.1309 * * *$ & $-0.1663 * * *$ \\
\hline & & & & & & $(8.75)$ & $(4.58)$ & $(5.60)$ & $(3.33)$ & $(4.14)$ \\
\hline African & & & & & & $-0.2017 * * *$ & $-0.2726^{* * *}$ & $-0.2659 * * *$ & $-0.1857 * * *$ & $-0.1349^{*}$ \\
\hline American & & & & & & $(5.48)$ & $(3.21)$ & $(3.64)$ & $(2.62)$ & (1.94) \\
\hline $\begin{array}{l}\text { Chow } \\
\text { statistic }\end{array}$ & $4.88 * * *$ & & & & & 0.97 & & & & \\
\hline$R$ squared & 0.0184 & 0.0193 & 0.0189 & 0.0186 & 0.0181 & 0.0836 & 0.0861 & 0.0809 & 0.0842 & 0.0861 \\
\hline $\begin{array}{l}\text { Number of } \\
\text { observations }\end{array}$ & 28,375 & 6,059 & 7,419 & 7,472 & 7,425 & 28,375 & 6,059 & 7,419 & 7,472 & 7,425 \\
\hline
\end{tabular}

Note: t-statistics are in parentheses, ${ }^{*}$ denotes statistical significance at $10 \%$ level, $* *$ denotes statistical significance at $5 \%$ level, and $* * *$ denotes statistical significance at $1 \%$ level.

checking deposits becomes a stable function of economic and demographic forces.

One important implication is that past aggregate time-series studies might have erred for neglecting the stabilizing effects of human capital and family formation variables on the demand for narrow money which is mainly held by households as normal goods or necessi- ties. If these findings can serve as a useful guide during periods of financial innovations, the impact of monetary policy on the economic activities of households may not be as unpredictable as those suggested in past time-series studies. In formulating monetary policies, however, decision-makers ought to consider not only the volatile relationship between money demand and the transactions 
motive but also the stabilizing effects of the life-cycle motive on money demand both directly and indirectly via real income and interest rate.

\section{Acknowledgements}

The views expressed here are those of the author and do not reflect those of the Commerce Department or the Census Bureau.

\section{Reference}

[1] J. R. Hicks, "Mr. Keynes and the Classics-A Suggested Interpretation," Econometrica, Vol. 5, No. 2, 1937, pp. 147-159. doi: $10.2307 / 1907242$

[2] I. Fisher, "The Purchasing Power of Money: Its Determination and Relation to Credit, Interest, and Crises," MacMillan, New York, 1911.

[3] W. J. Baumol, "The Transactions Demand for Cash: An Inventory-Theoretic Approach," Quarterly Journal of Economics, Vol. 66, No. 4, 1952, pp. 545-556. doi: $10.2307 / 1882104$

[4] J. Tobin, "The Interest Elasticity of the Transactions Demand for Cash," Review of Economics and Statistics, Vol. 38, No. 3, 1956, pp. 241-247. doi:10.2307/1925776

[5] M. Friedman, "The Quantity Theory of Money: A Restatement," In: M. Friedman, Ed., Studies in the Quantity Theory of Money, University of Chicago Press, Chicago, 1956.

[6] D. Laidler, "The Demand for Money: Theories and Evidence," Harper \& Row, New York, 1977.

[7] T. H. Lee, "Income, Wealth, and the Demand for Money: Some Evidence from Cross-Section Data," Journal of the American Statistical Association, Vol. 59, No. 307, 1964, pp. 46-62.

[8] F. H. Lydall, "Income, Assets, and the Demand for Money," Review of Economics and Statistics, Vol. 40, No. 1, 1958, pp. 1-14. doi:10.2307/1926475

[9] F. Modigliani and R. Brumberg, "Utility Analysis and the Consumption Function: An Interpretation of the Crosssection Data," In: K. Kurihara, Ed., Post-Keynesian Economics, Rutgers University Press, New Brunswick, 1954.

[10] B. P. Pesek, "Determinants of the Demand for Money," Review of Economics and Statistics, Vol. 45, No. 3, 1963, pp. 419-424. doi:10.2307/1927926

[11] S. Goldfeld, "The Demand for Money Revisited," Brookings Papers on Economic Activities, Vol. 1973, No. 3, pp. 577-638. doi: $10.2307 / 2534203$

[12] W. A. Barnett, E. K. Offenbacher and P. A. Spindt, "The New Divisia Monetary Aggregates," Journal of Political Economy, Vol. 92, No. 6, 1984, pp. 1049-1085. doi: $10.1086 / 261275$
[13] J. Carr and M. Darby, "The Role of Money Supply Shocks in the Short-Run Demand for Money," Journal of Monetary Economics, Vol. 8, No. 2, 1981, pp. 183-199. doi:10.1016/0304-3932(81)90024-6

[14] M. Friedman, "Lessons from the 1979-1982 Monetary Policy Experiment," The American Economic Review Papers and Proceedings, Vol. 74, No. 2, 1984, pp $397-$ 400.

[15] J. P. Judd and J. L. Scadding, "The Search for a Stable Money Demand Function: A Survey of the Post-1973 Literature," Journal of Economic Literature, Vol. 20, No. 3, 1982, pp. 993-1023.

[16] Y. Baba, D. F. Hendry and R. M. Starr, "The Demand for M1 in the USA 1960-1988," Review of Economic Studies, Vol. 59, No. 1, 1992, pp. 25-61. doi:10.2307/2297924

[17] B. Friedman and N. K. Kuttner, "Money, Income, Prices, and Interest Rates," American Economic Review, Vol. 82, No. 3, 1992, pp. 472-492.

[18] D. L. Hoffman and R. H. Rasche, "Long-Run Income and Interest Elasticities of Money Demand in the United States," Review of Economics and Statistics, Vol. 73, No. 4, 1991, pp. 665-674. doi:10.2307/2109405

[19] J. H. Stock and M. W. Watson, "A Simple Estimator of Cointegrating Vectors in Higher Order Integrated Systems," Econometrica, Vol. 61, No. 4, 1993, pp. 783-820. doi: $10.2307 / 2951763$

[20] R. G. Anderson and R. H. Rasche, "Retail Sweep Programs and Bank Reserves, 1994-1999," The Federal Reserve Bank of St. Louis, 2000, http://research.stlouisfed.org/wp/2000/2000-023.pdf

[21] L. Ball, "Another Look at Long-Run Money Demand," Journal of Monetary Economics, Vol. 47, No. 1, 2001, pp. 31-44. doi:10.1016/S0304-3932(00)00043-X

[22] K. Choi and C. Jung, "Structural Changes and the US Money Demand Function," Applied Economics, Vol. 41, No. 10, 2009, pp 1251-1257. doi:10.1080/00036840601007385

[23] D. H. Dutkowsky and B. Z. Cynamon, "Sweep Programs: The Fall of M1 and Rebirth of the Medium of Exchange," Journal of Money, Credit, and Banking, Vol. 35, No. 2, 2003, pp. 263-279. doi:10.1353/mcb.2003.0011

[24] B. B. Rao and S. Kumar, "Is the US Demand for Money Unstable?” MPRA Paper No. 15715, 2009. http://mpra.ub.uni-muenchen.de/15715

[25] J. M. Keynes, "The General Theory of Employment, Interest, and Money," MacMillan, London, 1936.

[26] J. Tin, "The Life-Cycle Motive and Money Demand: Further Evidence," Economics Bulletin, Vol. 5, No. 33, 2008, pp. 1-12.

[27] J. Tin, "Representative Economic Agent and Asset Demand Revisited," In: A. Tavidze, Ed., Progress in Economics Research, Nova Science Publishers, New York, 2010, pp. 45-86. 